\title{
Evaluation of Leachate Contamination Index Obtained from Dumpsite in Onitsha, Nigeria
}

\author{
Emmanuel Ikpe Michael* $^{*}$
}

Nnamdi Azikiwe University, Awka, Anambra State, Nigeria

\begin{abstract}
Physico-chemical and microbiological parameters were analyzed in leachate sample obtained at different locations (Obosi public dumpsite, groundwater and agricultural soil farmland $45.6 \mathrm{~km}$ from Onitsha dumpsite). This is to assess the impact of leachate and the effect of heavy metals on agricultural produce, Zea mays and Phaseolus vulgaris. In addition, $\mathrm{pH}$ values and the concentrations of these metals (Cd, $\mathrm{Ag}, \mathrm{Al}, \mathrm{Mo}, \mathrm{As}, \mathrm{Hg}, \mathrm{Mn}, \mathrm{Zn}, \mathrm{Cu}, \mathrm{Hi}, \mathrm{Cr}, \mathrm{Mg}, \mathrm{Fe}, \mathrm{Pb}$ and $\mathrm{Co}$ ) in dumpsite leachate, agricultural soil collected from a depth of $10 \mathrm{~cm}$ were assessed. The $\mathrm{pH}$ of the experimental samples ranged from 6.41-7.15. The analysis of samples for heavy metals revealed very high concentrations of $\mathrm{Mg}(14.20-20.23$ $\mathrm{ppm}), \mathrm{Hg}(0.002-2.29 \mathrm{ppm}), \mathrm{Pb}(0.09-0.65 \mathrm{ppm}), \mathrm{Cd}(0.001-0.53 \mathrm{ppm})$, but Al and As were not detected in most of the samples. Physiochemical parameters (Total dissolved Solid, Temperature, Conductivity, Turbidity, Cation Exchange Capacity, Color, Total Organic Carbon and Particle size) and Microbiological parameters (Total heterotrophic bacterial and fungal count) were analyzed using standard methods. The microbial enumeration showed heterotrophic bacterial and fungal count ranging from $12 \times 10^{5}$ to $2 \times 10^{5} \mathrm{cfu} / \mathrm{ml}$ for leachate and ground water samples. Heterotrophic fungal count ranged from $3 \times 10^{5}$ to $8 \times 10^{5} \mathrm{cfu} / \mathrm{ml}$ for leachate and ground water. Culture plate, structural form and biochemical characterization conducted on these isolates using Bergey's manual of determinative bacteriology. Fungal atlas was used to suggest possible identities of the fungal isolates. These isolates were molecularly identified by $16 \mathrm{~S}$ rDNA and ITS rDNA sequence analysis for bacterial and fungal isolates respectively. The bacterial identities were Lysinibacillus fusiformis and Klebsiella pneumoniae, while fungal isolates were identified as Aspergillus tamarii, and Aspergillus fumigatus. The leachate generated from Obosi overburden dumpsite has the potential to pollute the surrounding water.
\end{abstract}

Keywords: Leachate; Contamination index; Heavy metals; Dumpsite; Groundwater; Toxicity

\section{Introduction}

The accumulation of waste disposed in landfills has generated a waste water product known as leachate (8). Moreover, haphazard discharge of industrial and municipal effluent can result in environmental pollution with diverse heavy metal such as $(\mathrm{Zn}, \mathrm{Cr}, \mathrm{Cd}$, $\mathrm{Pb}$ ) [1-11]. Consequently, these heavy metals are been absorbed by plant through their root and eventually into the food chain of mammals feeding on plant for daily survival. These heavy metals are regarded to be very environmentally unfriendly. Thus, random disposal of such unexamined wastes indicates imminent harm to livelihood [5-20]. The rate of metal contamination in our soil environment result from the constant disposal of waste generated from industrial and municipal activities ranging from batteries, leads foils, glass, metallurgical process, inks, effluent of fertilizer companies and are highly recalcitrant in nature with their presence in the soil not easily be eliminate or degraded by soil organisms through metabolic processes $[4,21,22]$. The negative effect of heavy metals cannot be easily underestimated as it reduces the quality of soil. It has contending influence on the properties such as $\mathrm{pH}$ of the soil and eventually inhibiting the proliferation of microorganism due to high contamination overtime [12]. This research analysis study was geared toward evaluating the serious heavy metal contamination index of leachate collected from Onitsha dumpsite and also include the following below:

i) To determine the rates and extent of heavy metal contaminations and ascertain their distinction in $\mathrm{pH}$.

ii) To evaluate the heavy metal contamination index of leachate collected from Onitsha dumpsites on agricultural and microbial implications. Bioassays were used to establish the effect of toxicity because of their sensitivity to environmental stress.

\section{Materials and Methods}

\section{Study area}

Onitsha dumpsite was selected for study due to the age and anthropogenic activities. It is cited in the latitude of $6005^{\prime} 39^{\prime} \mathrm{N}$ to 60 $1213^{\prime \prime} \mathrm{N}$ of the equator and longitude $6045^{\prime} 29^{\prime} \mathrm{E}$ to $6050^{\prime} 07^{\prime \prime} \mathrm{E}$ of the Green which meridian, cited at Obosi along Onitsha-Owerri expressway on the eastern bank of the River Niger.

\section{Experimental set-up}

The choice on the research using leachate was to ascertain the effect of heavy metals on the growth of plant. Beans (Phaseolus vulgaris), maize (Zea mays) were employed as bioassays. Ground water was employed as a probe using an exsitu experimental set-up. Plant subjects were supplied with dumpsite leachate and ground water in different setup. Unsullied agricultural soil was obtained from a farmland $45.6 \mathrm{~km}$ from Onitsha dumpsite to ascertain significant differences.

\section{Leachate sampling}

Pooled sample of leachate collected from the dumpsite into a sterile BOD bottle and immediately preserved in an ice box $\left(4^{\circ} \mathrm{C}\right)$ and transported to the laboratory for analysis.

*Corresponding author: Emmanuel Ikpe Michael, Nnamdi Azikiwe University, Awka Anambra State, Nigeria, Tel: +07081610453; E-mail: emmanuelmichael001@yahoo.com

Received October 01, 2017; Accepted October 23, 2017; Published October 30, 2017

Citation: Michael El (2017) Evaluation of Leachate Contamination Index Obtained from Dumpsite in Onitsha, Nigeria. J Environ Anal Toxicol 7: 525. doi: 10.4172/21610525.1000525

Copyright: @ 2017 Michael El. This is an open-access article distributed under the terms of the Creative Commons Attribution License, which permits unrestricted use, distribution, and reproduction in any medium, provided the original author and source are credited. 


\section{Analysis of leachate organic content}

The following physicochemical parameter were examined; Temperature $\left({ }^{\circ} \mathrm{C}\right) \mathrm{pH}$, conductivity (us/cm), Turbidity (NTU), Color, total dissolved solid $(\mathrm{mg} / \mathrm{l})$.

\section{Chemical analysis}

The following metals are assessed from leachate; cadmium, silver, Aluminium, Molybdenium, Arsenic, Mercury, Magnesium, Zinc, Nickel, Chromium, Manganese, Iron, Lead and Cobalt. Heavy metals analyzed using Varian AA240 (Atomatic Absorption Spectrophometer) with method by APHA 1995 (American Public Health Association).

\section{Analysis of soil sample (Pristine agricultural soil)}

Pristine agricultural soil obtained for the experimental set-up was examined for the following physical and chemical parameters; $\mathrm{pH}$, Cation Exchange capacity ( $\mathrm{mol} / \mathrm{kg}$ ), Total organic carbon (\%), \%sand, $\%$ silt, \%clay. Different method were of adopted for the analysis of various parameters. The $\mathrm{pH}$ was measured by electrometric method using laboratory $\mathrm{pH}$ meter Hanna model H 1991300(APHA: 1998). The analysis of Total Dissolved Solid (TDS) was adopted by APHA 1998 using APHA 2510A TDS 139 tester.

\section{Microbiological enumeration}

Analysis of the total culturable heterotrophic bacterial and fungal count was carried out using method described by Jorgensen et al. Spread plate method using nutrient agar fortified with nystatin to inhabit fungal growth and Sabouraud dextrose agar (SDA) amended with chloramphenicol to impede bacterial growth to isolate bacterial growth to isolate bacterial and fungi within the incubation period of 18-24 hrs (bacterial culture) and 18-72 hrs (fungal culture) respectively. Colonies where expressed and expressed in colony forming unit per $\mathrm{ml}$ $(\mathrm{cfu} / \mathrm{ml})$. The suspensions of different sample $(9 \mathrm{ml}$ of distilled water in $1 \mathrm{~m}$ samples of experimental) was prepared and serially diluted to $10^{-5}$ via serial dilution with $1 \mathrm{ml}$ of leachate using distilled water as the diluents. $0.1 \mathrm{ml}$ aliquots of appropriate dilutions were spread on triplicates of sterile nutrient agar.

\section{Assessment of contamination index on pristine agriculture soil}

Municipal dumpsite leachate toxicity impact was ascertained using agriculture soil and bioassays Maize (Zea may) and beans (Phaseolus vulgaris). The phyto-toxicity analysis for samples was used in the cultivation of beans and maize plant as subjects. Petri dishes were used for experimental samples (leachate and ground water). 10 grains of beans and maize were planted and equally spaced in the petri dish. The experimental set-up ground water was used as control. The plants were constantly irrigated or sprinkled with leachate and ground water for experimental period of eight [8] weeks to observe significant differences in seed germinated in pollution media (leachate), germination in control media (ground water) and root elongation of both. According to the method of Millioli et al. and growth percentage calculation as follows below:

$$
\begin{aligned}
& \% I G=\frac{(\% S G) \times(\% G R)}{100} \\
& \% S G=\frac{(\% E G)}{(\% E G)} \times \frac{100}{1} \\
& \% G R=\frac{G E R m}{G E R C m} \times \frac{100}{1}
\end{aligned}
$$

Where \%SG=seed germination; \%GR=Growth of the roots; $\% \mathrm{EG}=$ Germination in pollution media; $\% \mathrm{CG}=$ Germination in control media; GER $m=$ Elongation of roots in pollution media; GERC $m=$ Elongation of root in control media.

\section{Results}

Onitsha dumpsite is averagely dominated with organic substances like plastics, glass, metals, woods, leather and untreated discharged effluent that affects the entire environment and eventually percolates into the groundwater and possess water borne diseases [20].

\section{Chemical analysis of agricultural soil, leachate and ground water used for experimental set-up}

The cation exchange capacity ( $\mathrm{mol} / \mathrm{kg}), \mathrm{pH}$, \% Total organic carbon, \%salt, \%silt, \%clay, heavy metals (Cd, Ag, Al, Mo, As, Hg, Mn, Zn, Cu, $\mathrm{Ni}, \mathrm{Cr}, \mathrm{Mg}, \mathrm{Fe}, \mathrm{Pb}$ and $\mathrm{Co}$ ) from dumpsite, leachate, agricultural soil were assessed. The $\mathrm{pH}$ ratio of agricultural soil, leachate and ground water samples range from 6.39-6.41, 7.14-7.16, 6.56 -6.58 respectively. The reason for high $\mathrm{pH}$ in Onitsha dumpsite leachate may obviously be due to the frequent discharge of industrial and municipal effluent into the dumpsite as compared with the $\mathrm{pH}$ of dumpsites in some cities in the South-West region of Nigeria such as Ekpoma $(6.00 \pm 0.24)$, Warri $(5.19 \pm 0.20)$ in previous research (1). Porteus reported high $\mathrm{pH}$ rate in the presence of heavy metals with the range of 6.0-9.0 and this high concentration have been known to percolate into the soil of the landfill (14). The average ratio of metal concentration in the soil, leachate and ground water in this study as indicated in Table 1. The ratio of the heavy metal concentrations in the leachate sample clearly indicates the high rate of anthropogenic influence that has adversely affected the environment. The adverse effect on the experimental bioassays (Beans and Maize) indicated how it inhibited their growth and the effect of heavy metal assessment expressing their line of action in inhibiting the growth by altering their physiological activities as well as morphologically decreases the functionality of plant structures [4] (Table 2).

The level of pollution by heavy metals in Onitsha dumpsite on seed germination as expressed in Table 3. This data indicates that Magnesium, Mercury, Molybdenium have pollution value of an extreme rate. Meanwhile, Arsenic, Aluminium, Chromium had significantly low rate of pollution and are of no threat to increase of pollutant in the leachate. Lead, Cobalt, Iron was relatively high compared to the standard of USEPA in 2002 [21]. Other metals had slightly significant and insignificant ratio in the leachate. Leachate, soil, ground water were analyzed for physical, chemical and biological parameters like Metals, Temperature, $\mathrm{pH}$, Conductivity, Turbidity, Color, Total Dissolved Solid (TDS) using standard methods of analysis.

\section{Correlation studies}

Heavy metal concentration studies in the experimental samples as shown in Figure 1. The correlation contamination index in excessive rate are categorized in the following order; $\mathrm{Mg} \geq \mathrm{Fe} \geq \mathrm{Mo} \geq \mathrm{Co} \geq \mathrm{Mn}$ $\geq \mathrm{Pb} \geq \mathrm{Cu} \geq \mathrm{Ni} \geq \mathrm{Ag} \geq \mathrm{Hg} \geq \mathrm{Cr} \geq \geq$ ( $\mathrm{Al}$ and $\mathrm{As}$ ) had very insignificant values (Ground water), $\mathrm{Mg} \geq \mathrm{Zn} \geq \mathrm{Mn} \geq \mathrm{Cu} \geq \mathrm{Ni} \geq \mathrm{Pb} \geq \mathrm{Co} \geq \mathrm{Hg}$ $\geq$ (Cr, Ag) $\geq$ (Al/Cd) $\geq$ Mo (Soil), $\mathrm{Mg} \geq \mathrm{Hg} \geq \mathrm{Mo} \geq \mathrm{Pb} \geq \mathrm{Cd} \geq \mathrm{Zn} \geq$ $\mathrm{Co} \geq(\mathrm{Ni} / \mathrm{Cu}) \geq \mathrm{Ag} \geq \mathrm{Fe} \geq \mathrm{Mn} \geq(\mathrm{Al} / \mathrm{Ar} / \mathrm{Cr})$ for leachate. The metal correlation relatively implies that they all originate from common source. This speculation may be correct due to the fact that several industrial effluents discharged into this dumpsite originate from various combinations of these metals. Scientific researches on metals and alloys indicate that alloys of metals are combined to increase the 


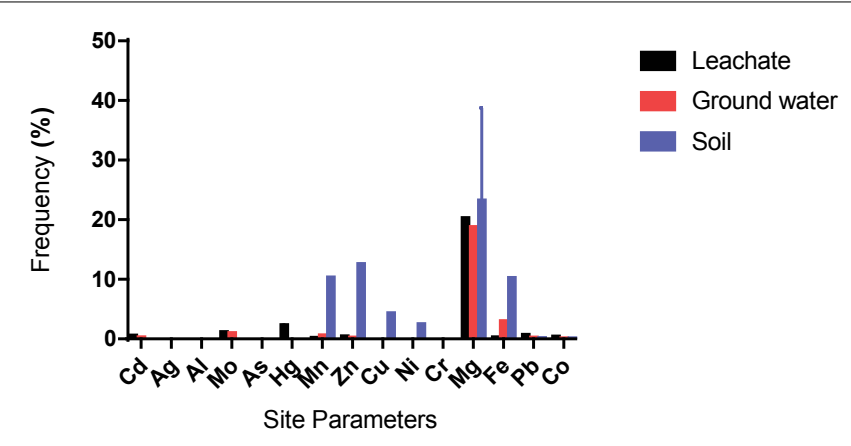

Figure 1: Chemical properties of leachate, ground water and agricultural soil.

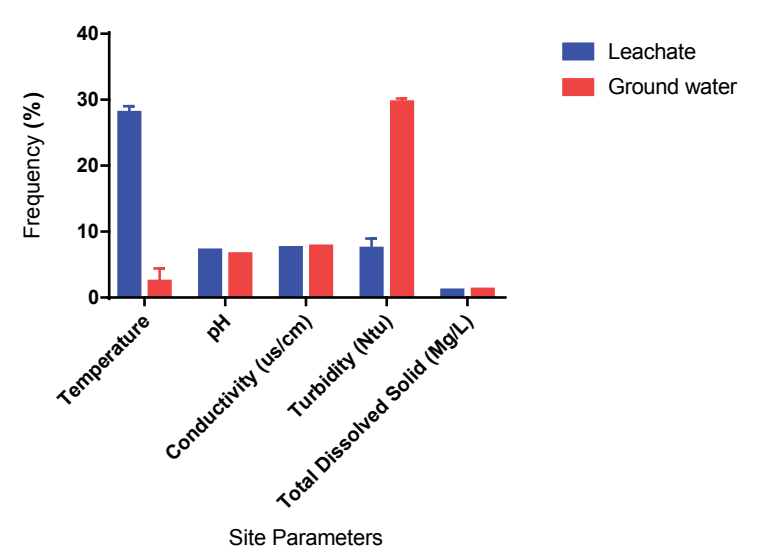

Figure 2: Physico-chemical parameters of leachate and ground water.

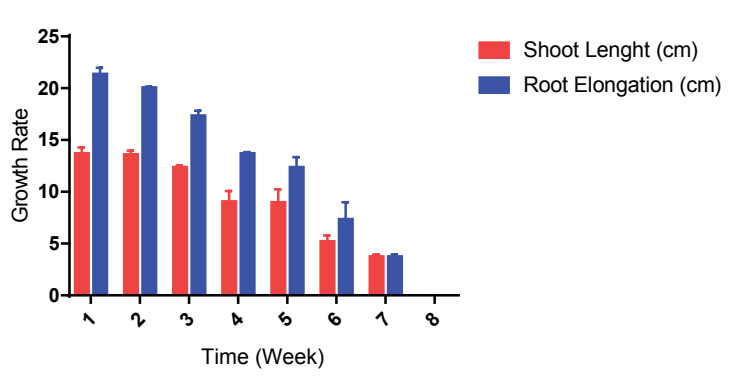

Figure 3: Rate of shoot length and elongation in Zea mays (Maize) irrigated with leachate sample in respect to weeks.

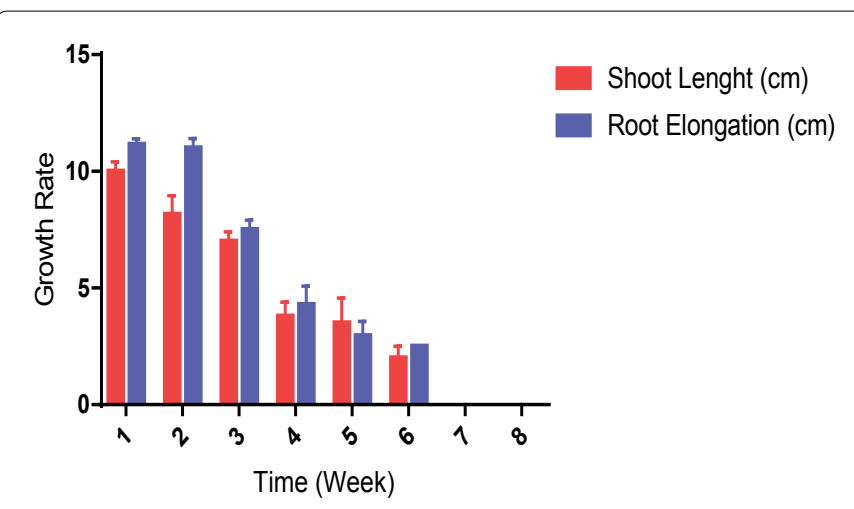

Figure 4: Rate of shoot length and elongation in Phaseolus vulgaris (Beans) irrigated with leachate sample in respect to weeks. purity of less valuable substances, especially during the process of electroplating metals $[9,16,18]$.

\section{Data analysis}

GraphPad Prism 7.00 Software was employed for the analysis of mean values and standard deviation $( \pm \mathrm{SD})$ using the three-mean data set result. Experimental data were obtained in replicate of three.

\section{Risk assessment of leachate on the growth of bioassays}

Evaluation of toxicity from the dumpsite leachate obtained for the experiment on bioassays indicated it result as an inhibitory substance due to the presence of high metals that were traceable to indiscriminate disposal of refuse and untreated industrial effluent. In accordance to the findings on the application of leachate on crops confirmed the toxicity of leachate on germinating plants [19] (Figures 2-5).

The mean correlation of germination rate of bioassays indicated in Table 4 showed that the beans and maize irrigated with leachate were inhibited as compared to that of the groundwater (control) as shown in Table 3. The germination curve of plants irrigated with leachate showed steady growth at week 1-3 and eventually reduced from week 4-7 due to the high level of toxicity from the leachate sample containing metal contaminant as their growth terminated at week 8 . Steady germination rate of plants subjected to groundwater had rapid and steady growth from week 1-8 to confirm the cause of inhibition in the leachate sample experimental set-up. Srinivas et al. recorded decrease in growth of plants due to high level of heavy metals concentration. The reason for reduction of shoot length as shown in Table 4 was due to the reduced meristematic cells and certain enzymes present in the endosperm and cotyledon cells that are responsible for the digestion and storage of food to be converted to soluble form for transportation to the tip of the radical and plumule. Adverse effect of heavy metals such as Lead and Nickel on enzymatic activities affects seed germination and growth of plants $[6,15,17]$.

\section{Microbial count and molecular identification}

The microbial enumeration showed heterotrophic bacterial and fungal count ranging from $12 \times 10^{5}$ to $2 \times 10^{5} \mathrm{cfu} / \mathrm{ml}$ for leachate and ground water samples. Heterotrophic fungal count ranged from $3 \times$ $10^{5}$ to $8 \times 10^{5} \mathrm{cfu} / \mathrm{ml}$ for leachate and ground water. The molecular identification performed by ITS rDNA sequence analysis using the FASTA algorithm with fungus data base from EBI. The fungal isolates were identified as Aspergillus tamarii and Aspergillus fumigatus and 16 $\mathrm{S}$ rDNA sequencing analysis, using FASTA algorithm with prokaryote

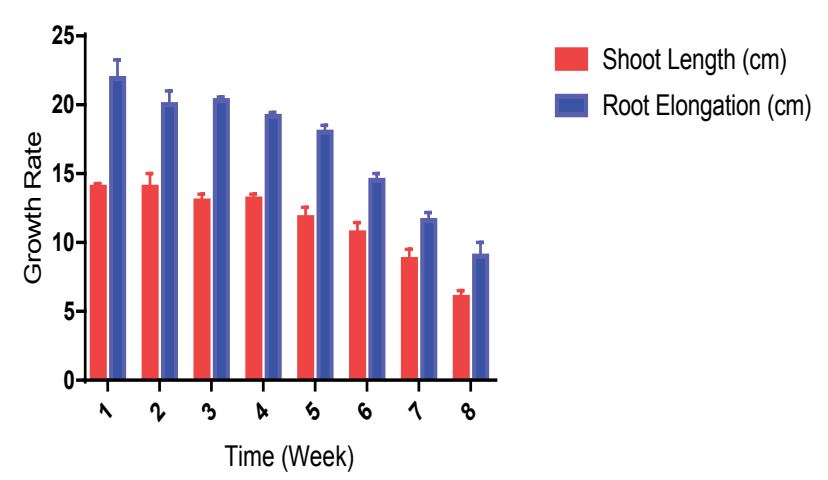

Figure 5: Rate of shoot length and elongation in Phaseolus vulgaris (Beans) irrigated with ground water sample in respect to weeks. 
Citation: Michael El (2017) Evaluation of Leachate Contamination Index Obtained from Dumpsite in Onitsha, Nigeria. J Environ Anal Toxicol 7: 525. doi: 10.4172/2161-0525.1000525

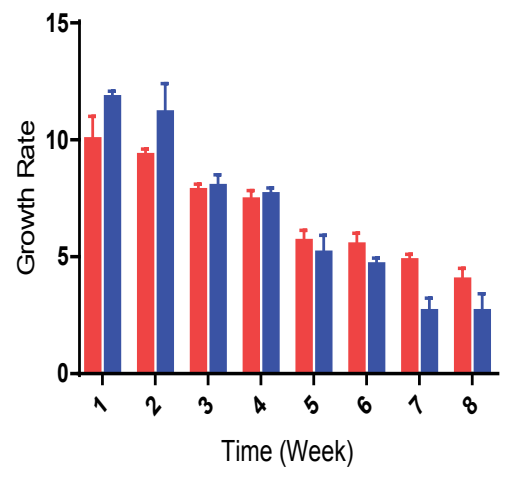

Shoot Length $(\mathrm{cm})$

Root Elongation (cm)

Figure 6: Rate of shoot length and elongation in Zea mays (Maize) irrigated with ground water sample in respect to weeks.

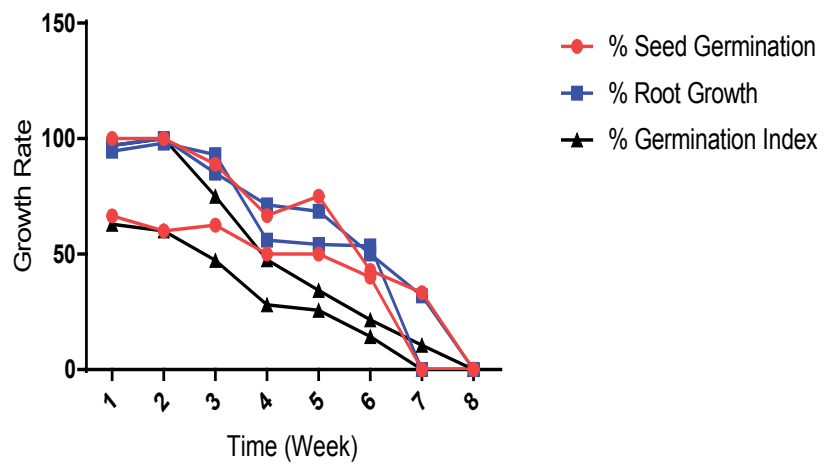

Figure 7: Rate of bioassay germination with leachate sample.

\begin{tabular}{|c|c|c|c|}
\hline Site Parameter & Leachate & Ground water & Soil \\
\hline Cadmium & $0.536 \pm 0.001$ & $0.24 \pm 0.001$ & $0.001 \pm 0.001$ \\
\hline Silver & $0.023 \pm 0.001$ & $0.015 \pm 0.0015$ & $0.002 \pm 0.001$ \\
\hline Aluminium & $0.003 \pm 0.005$ & $0.007 \pm 0.006$ & $0.002 \pm 0.001$ \\
\hline Molybdenium & $1.121 \pm 0.001$ & $0.923 \pm 0.001$ & $0.003 \pm 0.006$ \\
\hline Arsenic & $0.017 \pm 0.015$ & $0.003 \pm 0.006$ & $0.001 \pm 0.001$ \\
\hline Mercury & $2.291 \pm 0.001$ & $0.002 \pm 0.001$ & $0.009 \pm 0.001$ \\
\hline Manganese & $0.131 \pm 0.001$ & $0.542 \pm 0.001$ & $10.250 \pm 0.001$ \\
\hline Zinc & $0.402 \pm 0.001$ & $0.187 \pm 0.001$ & $12.500 \pm 0.001$ \\
\hline Copper & $0.027 \pm 0.001$ & $0.031 \pm 0.001$ & $4.260 \pm 0.001$ \\
\hline Nickel & $0.027 \pm 0.002$ & $0.032 \pm 0.001$ & $2.421 \pm 0.001$ \\
\hline Chromium & $0.017 \pm 0.015$ & $0.002 \pm 0.001$ & $0.002 \pm 0.001$ \\
\hline Magnesium & $20.233 \pm 0.001$ & $18.717 \pm 0.002$ & $\mathrm{ppm}$ \\
\hline Iron & $0.215 \pm 0.001$ & $2.917 \pm 0.001$ & $\mathrm{ppm}$ \\
\hline Lead & $0.655 \pm 0.001$ & $0.197 \pm 0.001$ & $23.200 \pm 15.588$ \\
\hline Cobalt & $0.363 \pm 0.001$ & $0.081 \pm 0.001$ & $10.200 \pm 0.001$ \\
\hline
\end{tabular}

Results are Means of Triplicate Determination \pm Standard Deviation (SD).

Table 1: Chemical Properties of Leachate, Agriculture Soil and Ground Water. 
Citation: Michael El (2017) Evaluation of Leachate Contamination Index Obtained from Dumpsite in Onitsha, Nigeria. J Environ Anal Toxicol 7: 525. doi: 10.4172/2161-0525.1000525

Page 5 of 6

\begin{tabular}{|c|c|c|c|}
\hline Site Parameter & Soil Sample & Parameters & Lechate Sample \\
\hline $\mathrm{pH}$ & $\begin{array}{c}\text { Mean } \pm \text { SD } \\
6.407 \pm 0.015\end{array}$ & Temperature $\left({ }^{\circ} \mathrm{C}\right)$ & $\begin{array}{c}\text { Mean } \pm \text { SD } \\
28 \pm 1.0\end{array}$ \\
\hline $\begin{array}{c}\text { Cation Exchange Capacity } \\
\text { (Mol/kg) }\end{array}$ & $0.015 \pm 0.0001$ & $\mathrm{pH}$ & $7.15 \pm 0.01$ \\
\hline Total Organic Carbon (\%) & $0.160 \pm 0.0001$ & Conductivity (us/cm) & $7.50 \pm 0.01$ \\
\hline$\%$ sand & $49.22 \pm 0.015$ & Turbidity (Ntu) & $7.43 \pm 1.53$ \\
\hline \% clay & $27.00 \pm 1.000$ & Color & $29.6 \pm 0.577$ \\
\hline
\end{tabular}

Results are Means of Triplicate Determination \pm Standard Deviation (SD).

Table 2: Physico-Chemical Parameters of Ground Water and Agriculture Soil.

\begin{tabular}{|c|c|c|c|c|}
\hline Weeks & Plants & No of Germinated Seed & Shoot Length (cm) & Root Elongation $(\mathrm{cm})$ \\
\hline Wk 1 & $\begin{array}{c}\text { Leachate } \\
\text { Maize } \\
\text { Beans } \\
\text { Ground water } \\
\text { Maize } \\
\text { Beans }\end{array}$ & $\begin{array}{c}10 \\
6 \\
10 \\
9\end{array}$ & $\begin{array}{c}\text { Mean } \pm \text { SD } \\
13.66 \pm 0.62 \\
10.00 \pm 0.40 \\
\\
14.0 \pm 0.28 \\
10.0 \pm 1.0\end{array}$ & $\begin{array}{c}\text { Mean } \pm \text { SD } \\
21.33 \pm 0.62 \\
11.16 \pm 0.23 \\
\\
21.9 \pm 1.37 \\
11.16 \pm 0.28\end{array}$ \\
\hline Wk 2 & $\begin{array}{c}\text { Leachate } \\
\text { Maize } \\
\text { Beans } \\
\text { Ground water } \\
\text { Maize } \\
\text { Beans }\end{array}$ & $\begin{array}{c}10 \\
6 \\
10 \\
10\end{array}$ & $\begin{array}{c}13.56 \pm 0.41 \\
8.16 \pm 0.80 \\
14.0 \pm 1.00 \\
9.33 \pm 0.28\end{array}$ & $\begin{array}{c}20.00 \pm 0.16 \\
11.00 \pm 0.40 \\
20.0 \pm 1.00 \\
11.16 \pm 1.25\end{array}$ \\
\hline Wk 3 & $\begin{array}{c}\text { Leachate } \\
\text { Maize } \\
\text { Beans } \\
\text { Ground water } \\
\text { Maize } \\
\text { Beans }\end{array}$ & $\begin{array}{l}8 \\
5 \\
\\
9 \\
8\end{array}$ & $\begin{array}{c}12.33 \pm 0.22 \\
7.00 \pm 0.40 \\
13.0 \pm 0.50 \\
7.83 \pm 0.28\end{array}$ & $\begin{array}{c}17.30 \pm 0.53 \\
7.50 \pm 0.40 \\
\\
20.3 \pm 0.28 \\
8.0 \pm 0.50\end{array}$ \\
\hline Wk 4 & $\begin{array}{c}\text { Leachate } \\
\text { Maize } \\
\text { Beans } \\
\text { Ground water } \\
\text { Maize } \\
\text { Beans }\end{array}$ & $\begin{array}{l}6 \\
4 \\
9 \\
8\end{array}$ & $\begin{array}{c}9.00 \pm 1.07 \\
3.80 \pm 0.60 \\
13.16 \pm 0.35 \\
7.43 \pm 0.40\end{array}$ & $\begin{array}{c}13.66 \pm 0.16 \\
4.30 \pm 0.78 \\
19.16 \pm 0.28 \\
7.66 \pm 0.28\end{array}$ \\
\hline Wk 5 & $\begin{array}{c}\text { Leachate } \\
\text { Maize } \\
\text { Beans } \\
\text { Ground water } \\
\text { Maize } \\
\text { Beans }\end{array}$ & $\begin{array}{l}6 \\
3 \\
8 \\
6\end{array}$ & $\begin{array}{l}8.93 \pm 1.30 \\
3.50 \pm 1.07 \\
11.8 \pm 0.76 \\
5.66 \pm 0.47\end{array}$ & $\begin{array}{c}12.33 \pm 1.01 \\
2.96 \pm 0.61 \\
18.0 \pm 0.5 \\
5.16 \pm 0.76\end{array}$ \\
\hline Wk 6 & $\begin{array}{c}\text { Leachate } \\
\text { Maize } \\
\text { Beans } \\
\text { Ground water } \\
\text { Maize } \\
\text { Beans }\end{array}$ & $\begin{array}{l}3 \\
2 \\
7 \\
5\end{array}$ & $\begin{array}{l}5.16 \pm 0.62 \\
2.00 \pm 0.50 \\
10.7 \pm 0.75 \\
5.50 \pm 0.50\end{array}$ & $\begin{array}{l}7.30 \pm 1.69 \\
2.50 \pm 0.00 \\
14.5 \pm 0.50 \\
4.66 \pm 0.28\end{array}$ \\
\hline Wk 7 & $\begin{array}{c}\text { Leachate } \\
\text { Maize } \\
\text { Beans } \\
\text { Ground water } \\
\text { Maize } \\
\text { Beans }\end{array}$ & $\begin{array}{c}2 \\
\text { NG } \\
6 \\
3\end{array}$ & $\begin{array}{c}3.7 \pm 0.24 \\
- \\
8.76 \pm 0.75 \\
4.83 \pm 0.28\end{array}$ & $\begin{array}{c}3.7 \pm 0.24 \\
- \\
11.6 \pm 0.57 \\
2.66 \pm 0.57\end{array}$ \\
\hline Wk 8 & $\begin{array}{c}\text { Leachate } \\
\text { Maize } \\
\text { Beans } \\
\text { Ground water } \\
\text { Maize } \\
\text { Beans }\end{array}$ & $\begin{array}{c}\text { NG } \\
- \\
4 \\
3\end{array}$ & $\begin{array}{c}- \\
- \\
6.0 \pm 0.5 \\
4.0 \pm 0.5\end{array}$ & $\begin{array}{c}- \\
- \\
9.0 \pm 1.0 \\
2.66 \pm 0.76\end{array}$ \\
\hline
\end{tabular}

Results are Means of Triplicate Determination \pm Standard Deviation (SD). NG=No Growth

Table 3: Rate of Shoot Length and Root Elongation Using Leachate and Ground water Sample. 
Citation: Michael El (2017) Evaluation of Leachate Contamination Index Obtained from Dumpsite in Onitsha, Nigeria. J Environ Anal Toxicol 7: 525. doi: 10.4172/2161-0525.1000525

Page 6 of 6

\begin{tabular}{|c|c|c|c|c|c|c|}
\hline \multirow[t]{2}{*}{ Weeks } & \multicolumn{2}{|c|}{$\%$ Seed germination $=\frac{\% E G}{\% C G} \times \frac{100}{1}$} & \multicolumn{2}{|c|}{$\%$ Root Growth $=\frac{\% G E R}{\% \text { GERcm }} \times \frac{100}{1}$} & \multicolumn{2}{|c|}{ Germination Index $(\%)=\frac{\% S G}{100} \times \frac{\% C G}{1}$} \\
\hline & Maize & Beans & Maize & Beans & Maize & Beans \\
\hline Wk 1 & 100 & 66.6 & 97.1 & 94.3 & 97.1 & 62.9 \\
\hline Wk 2 & 100 & 60 & 100 & 98.0 & 100 & 60 \\
\hline Wk 3 & 88.9 & 62.5 & 85 & 93 & 75 & 47.3 \\
\hline Wk 4 & 66.7 & 50 & 71.3 & 56.1 & 47.6 & 28.1 \\
\hline Wk 5 & 75 & 50 & 68.5 & 54.2 & 34.3 & 25.7 \\
\hline Wk 6 & 42.9 & 40 & 50 & 53.6 & 21.5 & 14.3 \\
\hline Wk 7 & 33.3 & - & 31.9 & - & 10.6 & - \\
\hline Wk 8 & - & - & - & - & - & - \\
\hline
\end{tabular}

Results are Means of Triplicate Determination \pm Standard Deviation (SD)

Table 4: \% Rate of Bioassay Germination with Leachate Sample.

database from EBI was employed and bacterial isolates were identified as Lysinibacillus fusiformis and Klebsiella pneumoniae for leachate (Figures 6 and 7).

\section{Conclusion}

The characteristics of the leachate obtained from Onitsha dumpsite, Obosi along Onitsha-Owerri expressway Anambra State of Nigeria. In this research work, it was observed that the high toxicity level of the heavy metals in leachate sample tested on bioassays (plants) inhibited germination as it decreases with increase in number of weeks. The decrease in number of germinated plants (maize and beans) was due to the high accumulation of heavy metals like $\mathrm{Cd}, \mathrm{Pb}, \mathrm{Zn}$, and Ag especially in leachate sample. All the samples contain heavy metals in different concentration and leachate sample had the highest concentration of heavy metals against ground water that served as control.

\section{Acknowledgements}

Much thanks to the United Kingdom CABI Molecular Identification Services toward identification of the microbial isolates.

\section{References}

1. Agatemor C, Agatemor UM (2010) Physiochemical Characteristics of well waters in four urban centers in Southern Nigeria. Environmentalist 30: 333-339.

2. American Public Association (1998) 311B, Directed Air-Acetelyne flame methods, for the Examination of water and waste. 20th edn. APHA, AWWWA, WEF.

3. American Public Health Association (1995) 3112B, Cold-vapour Atomatic Absorption spectrometric method, standard method for the Examination of water and waste water. 20th edn, APHA, AWWA, WEF.

4. Cheng S (2003) Effects of heavy metals on plants and resistance mechanisms. Environmental Science and Pollution Research 10: 256-264.

5. Ebong GA, Etuk HS, Johnson AS (2007) Heavy Metals Accumlation by Talinum. Triangulare Grown on waster Dumpsites in Uyo Metropolis Akwa Ibom State, Nigieria. J Appl Sci 7: 1404-1409.

6. Godbold DL, Kettner C (1991) Lead influences root growth and mineral nutrition of Picea abies seedlings. Journal of Plant Physiology 139: 95-99.

7. Jørgensen R, Søgaard TM, Rossing AB, Martensen PM, Justesen J (2000) Identification and characterization of human mitochondrial tryptophanyl-tRNA synthetase. Journal of Biological Chemistry 275: 16820-16826.

8. Abu-Daabes M, Qdais HA, Alsyouri H (2013) Assessment of heavy metals and organics in municipal solid waste leachates from landfills with different ages in Jordan. Journal of Environmental Protection 4: 344

9. Matthiessen A, von Bose M (1860) On the Lead-zinc and Bismuth-zinc Alloys Proceedings of the Royal Society of London 11: 430-433.

10. Millioli VS, Servulo EL, Sobral LG, De Carvalho DD (2009) Bioremediation of crude oil-bearing soil: evaluating the effect of rhamnolipid addition to soil toxicity and to crude oil bioregradation efficiency. Global NEST Journal 11: 181-188.

11. Mpofil K, Nyamugafata P, Maposa I, Nyoni K (2013) Impact of wastes dumping on Pomona medium sand clay Loam soils and surface water quality in Harare, Zimbabwe. ARPN Journal of Science and Technology 3: 1215-1221.

12. Nwuche CO, Ugoji EO (2008) Effects of heavy metal pollution on the soil microbial activity. International Journal of Environmental Science \& Technology 5: 409-414.

13. Ojiako JC, Emengini EJ, Iwuchukwu JN (2012) Geographic Information System (GIS) Approach to Solid Waste Management in Onitsha Urban Anambra State, Nigeria. International Journal of Scientific \& Engineering Research 5: 781-789.

14. Porteus A (1985) Hazardous Waste Management Handbook. Butterworth and Co Publishers, UK. pp: 146-166.

15. Sharifah BA, Hishashi O (1992) Effect of lead, cadmium and zinc on the cel elongation of Impatiens balsmina. Environmental and Experimental Botany 32 439-448.

16. Järup L, Bellander T, Hogstedt C, Spång G (1998) Mortality and cancer incidence in Swedish battery workers exposed to cadmium and nickel Occupational and Environmental Medicine 55: 755-759.

17. Srinivas J, Purushotham AV, Murali-Krishua KVSG (2013) The Effect of Heavy Metals on Seed Germination and Plant Growth on Coccina, Mentha and Trigonella Plant Seeds in Tamma Puram, EG District, Andhra Pradesh, India 2: $20-24$.

18. Sunthankar M (1991) Environmentally Safer Zinc-Cadmium Alloy Dry Plating as a Substitute for Cadmium Electroplating. US EPA Small Business Innovation Research, Pollution Prevention/Sustainable Development, USA.

19. Turki N, Bouzid J (2017) Effect of Landfill Leachate Application on Crops Growth and Properties of a Mediterranean Sandy Soil. Journal of Pollution Effect 5: 186.

20. Uba S, Uzairu A, Harrison GFS, Balarabe ML, Okunola OJ (2007) Assessment of Heavy Metals Bioavailability in Dumpsites in Zaria Metropolis, Nigeria. African Journal of Biotechnology 7: 122-130.

21. USEPA (United States Environment Protection Agency) (2002) Standard National Primary Drinking Water Standard EPA 816-F-02-013. Dated July 2002.

22. Nda-Umar UI, Nathaniel GS, Mann A, Yisa J (2012) Assessment of heavy metal species in some decomposed municipal solid wastes in Bida, Niger State, Nigeria. Advances in Analytical Chemistry 2: 6-9. 